\title{
Comparisons of milk quality on North Carolina organic and conventional dairies
}

\author{
K. A. E. Mullen, ${ }^{*}$ L. G. Sparks, $†$ R. L. Lyman,† S. P. Washburn, ${ }^{*}$ and K. L. Anderson ${ }^{1}$ \\ *Department of Animal Science, and \\ †Department of Population Health and Pathobiology, North Carolina State University, Raleigh 27695
}

\begin{abstract}
The organic dairy industry is growing rapidly across the United States and has recently expanded into the southeastern states. To date, no published comparisons of milk quality exist between organic and conventional dairies in the Southeastern United States. Maintaining high milk quality is challenging in this region due to the longer periods of high heat and humidity. The objective of this observational study was to compare milk quality on organic and conventional dairies in North Carolina during the warm summer months of the year. Data were compared from 7 organically and 7 conventionally managed herds in North Carolina. To assess milk quality, milk samples were aseptically collected from each functional quarter of each cow in the milking herds at the time of sampling and linear somatic cell scores (SCS) were obtained for individual cows. A total of 4,793 quarter milk samples (2,526 conventional and 2,267 organic) were collected from 1,247 cows (652 conventional and 595 organic). Milk samples were cultured and bacterial growth was identified using protocols consistent with those of the National Mastitis Council (Verona, WI). Subclinical mastitis was defined as the presence of SCS $\geq 4$ and also a microbiological infection in at least 1 quarter. The proportion of cows with subclinical mastitis did not differ between conventional $(20.8 \%)$ and organic $(23.3 \%)$ herds. No significant difference was observed between herd management types in the proportion of cows without microbiological growth in milk samples. Also, no significant differences were observed between organic and conventional herds for cow-level prevalence of Staphylococcus aureus, coagulase-negative Staphylococcus spp., Streptococcus spp., or Corynebacterium spp. Two of the organic herds had a notably higher prevalence of Corynebacterium spp. and higher SCS. Coliforms were found in 5 of 7 conventional herds and in only 1 of 7 organic herds. Mean SCS did not differ between conventional $(3.3 \pm 0.2)$
\end{abstract}

Received December 21, 2012.

Accepted June 27, 2013.

${ }^{1}$ Corresponding author: kevin_anderson@ncsu.edu and organic $(3.5 \pm 0.2)$ herds. Despite differences in herd management, milk quality was remarkably similar between the organic and conventional dairies compared for this study.

Key words: organic, milk quality, mastitis, somatic cell score

\section{INTRODUCTION}

The organic industry of the United States is growing steadily due to increasing consumer demand. In 2010, organic food sales reached $\$ 28.6$ billion, representing $4.0 \%$ of the total United States food market. Organic dairy products are the second-largest category of organic foods and sales in 2010 were $\$ 3.9$ billion, representing almost $6 \%$ of all marketed dairy products in the United States (Organic Trade Association, 2011). The growth of the United States organic dairy industry is fueled by the willingness of some consumers in the United States to pay more for dairy products produced without the use of antibiotics and with documented pasture access for dairy cattle (Olynk et al., 2010).

Mastitis, or mammary inflammation, represents a significant economic challenge to the dairy industry. Mastitis management is potentially more difficult on organic farms in the United States because certified organic dairy farms in the United States are prohibited from using antibiotics in their cattle. However, treatment cannot be withheld from a sick animal, and if an animal is treated with antibiotics, it cannot return to the organic herd and products from it cannot be sold as organic (USDA National Organic Program, 2013). Organic regulations in the United States emphasize prevention rather than treatment of disease. Organic cattle must also have year-round access to the outdoors, at least a 120-d grazing season on organic pastures, and obtain at least $30 \%$ of their DMI from those pastures during the grazing season (USDA National Organic Program, 2013).

Few studies have compared milk quality in organic and conventional production systems in the United States. Most of those studies have been performed in Wisconsin (Sato et al., 2005; Pol and Ruegg, 2007b) or other northern states (Zwald et al., 2004; Stiglbauer et 
al., 2013). No studies comparing organic and conventional dairy production in the southeastern states have been published. The heat and humidity of the southeast provide favorable conditions for the growth of environmental bacteria and increase the risk of mastitis. Heat stress compromises the udder's defense mechanisms (Giesecke, 1985) and increases SCS in Holstein and Jersey cattle (Smith et al., 2013). The southeast United States also faces significant challenges with regard to meeting lower SCC limits (Norman et al., 2000).

Mastitis is a challenge for many southeast dairy producers, particularly in summer, and the limited availability of effective treatments for mastitis in organic dairy cattle raises questions about the ability to maintain high-quality milk in organic herds in the region. Currently, 6 certified organic dairy herds produce milk in North Carolina. One pasture-based research herd manages half of its cattle using organic health care standards, whereas the other half of the herd is managed conventionally. The objective of the current study was to compare milk quality in organic versus conventional dairies in North Carolina during the warm months.

\section{MATERIALS AND METHODS}

\section{Regulatory Compliance}

All sample collections from cows were performed in accordance with the North Carolina State University Institutional Animal Care and Use Committee (Raleigh) approved protocol 11-029-A.

\section{Farm Selection and Surveys}

In 2010, owners of all certified organic dairy farms in North Carolina $(\mathrm{n}=6)$ were contacted and all agreed to participate in the study. Six conventionally managed dairy farms of similar size and geographical locations were recruited by personal contact of the authors. Also, a pasture-based research farm was included in this study. That research herd in North Carolina has managed half of its herd using organic health standards since 2009 and those organic cattle graze in transitioned pastures that can be certified organic. The other half of the herd is managed with conventional disease treatments, including antibiotic therapy at dry off and antibiotic treatment of mastitis. All cows in the research herd meet the $30 \%$ of DMI organic pasture requirement but they did receive supplemental concentrates that were not organically produced. Both management groups are milked in the same parlor, but otherwise do not have contact with each other. The research herd was considered as 2 separate herds in the analysis.
A written survey was developed by one of the authors (L. G. Sparks) to evaluate herd health management practices related to milk quality. Questions included basic farm demographics, milking protocols, fly control, and detection and treatments of subclinical and clinical mastitis. Farm demographics included breed(s) of cattle, number of lactating cattle, number of people milking cows, number of years certified organic, and the most recent bulk tank SCC. Surveys were given to farmers to fill out during farm visits while samples were being collected. Farmers were not compensated for participating in the study, but they were provided all milk culture results from cows in their respective herds.

\section{Sample Collection}

Milk samples were aseptically collected once from each functional quarter of all lactating cows in each herd between May and October of 2010. The average temperature during those months was $23^{\circ} \mathrm{C}\left(74^{\circ} \mathrm{F}\right)$ with an average of $70 \%$ relative humidity, with temperatures ranging from 17.9 to $27.4^{\circ} \mathrm{C}\left(64.3\right.$ to $\left.81.3^{\circ} \mathrm{F}\right)$ and relative humidity ranging from 40 to $101 \%$ (State Climate Office of North Carolina, 2013). Only those cows that contributed milk to the bulk tank were sampled, as cows with clinical mastitis were not part of the protocol for the current study. Briefly, teats were predipped with the teat germicide used on the farm and wiped dry using the normal milking preparation procedure of the farm being sampled; 2 to 4 streams of foremilk were expressed and then teat ends were cleaned using cotton balls soaked in $70 \%$ isopropanol. Samples were collected into $12-\mathrm{mL}$ vials, cooled, and then frozen overnight before milk culture. Linear SCS were obtained for individual cows within the sampled herds from the most recent monthly DHIA test if they participated in monthly testing. In those herds not on a monthly testing schedule with DHIA $(\mathrm{n}=4)$, milk samples were collected from each cow, taking an equal amount of milk from each functional teat into a tube containing a bronopol tablet preservative. The samples were shipped to the United DHIA Laboratory (Blacksburg, VA) for SCC analysis. Monthly test data were given as SCS and thus results here are presented as SCS. The SCS was calculated using the formula $\log _{2}\left(\frac{\mathrm{SCC}}{100,000}\right)+3$ to obtain the base 2 logarithmic transformation as recommended by Shook (1982).

\section{Milk Culture}

Microbiological analysis was performed in the Milk Quality and Mastitis Laboratory at the College of Veterinary Medicine at North Carolina State Univer- 
sity. Microbiological identification was performed using methods consistent with those of the National Mastitis Council (NMC, 1999). Briefly, $0.01 \mathrm{~mL}$ of milk from each sample was plated on Trypticase soy agar with $5 \%$ sheep blood (BD, Sparks, MD), incubated at $37^{\circ} \mathrm{C}$, and examined for growth after $24 \mathrm{~h}$ and again after $48 \mathrm{~h}$. Samples were considered contaminated if 3 or more dissimilar colony types were present. Otherwise, all colonies were identified using standard microbiological procedures (NMC, 1999). Streptococci were distinguished from enterococci using the Christie, Atkins, and Munch-Petersen (CAMP) test, esculin hydrolysis, and growth on bile esculin agar with azide (Hardy Diagnostics, Santa Maria, CA). If required, species were determined using the API20 Strep identification system (bioMérieux Inc., Durham, NC). Coagulase-negative staphylococci were distinguished from Staphylococcus aureus by mannitol fermentation and coagulase testing. Gram-negative rods were identified using morphology on MacConkey agar (Hardy Diagnostics), oxidase testing, and the API 20E identification system (bioMérieux Inc.), if required.

Culture results were recorded and are reported on a per-quarter basis. However, quarter milk culture data were pooled within cow to facilitate comparison with SCS, which was available on a cow basis. Cows with only a single bacterial species in 1 or more quarters were classified as being infected with that organism on a cow basis; these species included Staph. aureus, CNS, Streptococcus spp. other than Streptococcus agalactiae, and Corynebacterium spp. Cows with more than 1 bacterial species were classified as having mixed infections. To facilitate statistical analysis, only cows with infections attributed to one of the organisms listed above were considered. Cows with either Corynebacterium spp. or CNS or both were classified as cows with minor species infections. Subclinical mastitis was defined as the presence of a SCS $\geq 4$ and presence of any microbiological infection in 1 or more quarters.

\section{Statistical Analyses}

The MIXED procedure of SAS (version 9.2; SAS Institute Inc., Cary, NC) was used to analyze SCS data, with a general linear mixed model incorporating management type as a fixed effect and farm within management type as a random effect. Management type was included in the model to allow for comparisons between organic and conventional dairies. Farm within management type was also included in the model to account for variation in farm management and farm size within the organic and conventional groupings. Farms were not grouped by size due to the small sample size and consequent low statistical power to detect differences between size groups. The model for this analysis was $Y=X \beta+Z \gamma+\varepsilon$, where $Y$ is the continuous variable SCS and the expectation of Y, $E(Y)=X^{\prime} \beta, X \beta$ represents the effect of management type, $Z \gamma$ represents the effect of farm within type, and $\varepsilon$ is the error term. Results are given as least squares means.

Logistic regression was used to model the cow-level prevalence of different bacterial infections. This was performed using the GLIMMIX procedure of SAS (version 9.2; SAS Institute Inc.). The model incorporated management type as a fixed-effect factor, SCS as a quantitative fixed-effect explanatory variable, and farm within management type as a random-effect factor. Results were recorded as presence or absence of infection of each pathogen in each cow. The result of interest, $\pi=P($ infection $=1)$; that is, $\pi$ is the probability of an infection being present, was modeled using the logit function $Y=\operatorname{logit}\left(\frac{\pi}{1-\pi}\right)$. The logistic regression model was $Y=\mathbf{X} \boldsymbol{\beta}+Z \gamma+\varepsilon$, where $\boldsymbol{\beta}$ represents a vector of fixed effects including management type and SCS, $\mathbf{X}$ is the incidence matrix of fixed effects, $Z \gamma$ accounts for the random effect of farm within management type, and $\varepsilon$ is the random effect of the residuals due to modeling with $\mathrm{R}$ side effects. Least squares means were transformed using the equation $\hat{\pi}=\frac{1}{1+\exp (X \hat{\beta})}$ to express least squares means on a probability scale.

Results are reported as least squares means except in Table 3, where raw data are presented. Differences were considered significant at $P<0.05$.

\section{RESULTS}

\section{Farm Survey}

Farm Demographics. Dairy herds surveyed contained Holstein, Jersey, Guernsey, Brown Swiss, and crossbred cattle and ranged in size from 18 to 157 lactating cattle, as shown in Table 1. Only 5 herds had a single breed of cattle, in all cases Holsteins (Table $1)$. The 6 certified organic herds had transitioned to organic production in 2007 or 2008 and had been organic for at least $2 \mathrm{yr}$ at the time of this survey. The research herd had been managing half of its cattle following US Department of Agriculture (USDA) organic health care practices since 2009. Annual milk production ranged from 5,942 to $11,612 \mathrm{~kg}$ in conventional herds, with 3.5 to $4.7 \%$ fat and 2.9 to $3.1 \%$ protein. Organic herds produced between 4,536 and $7,031 \mathrm{~kg}$ of milk annually, with 3.3 to $4.6 \%$ fat and 2.9 to $3.7 \%$ protein. The most recent bulk tank SCC reported ranged from 180,000 to 390,000 cells $/ \mathrm{mL}$ in conventional herds 
Table 1. Demographics of 7 organic and 7 conventional dairy herds in North Carolina as reported by farmer surveys ${ }^{1}$

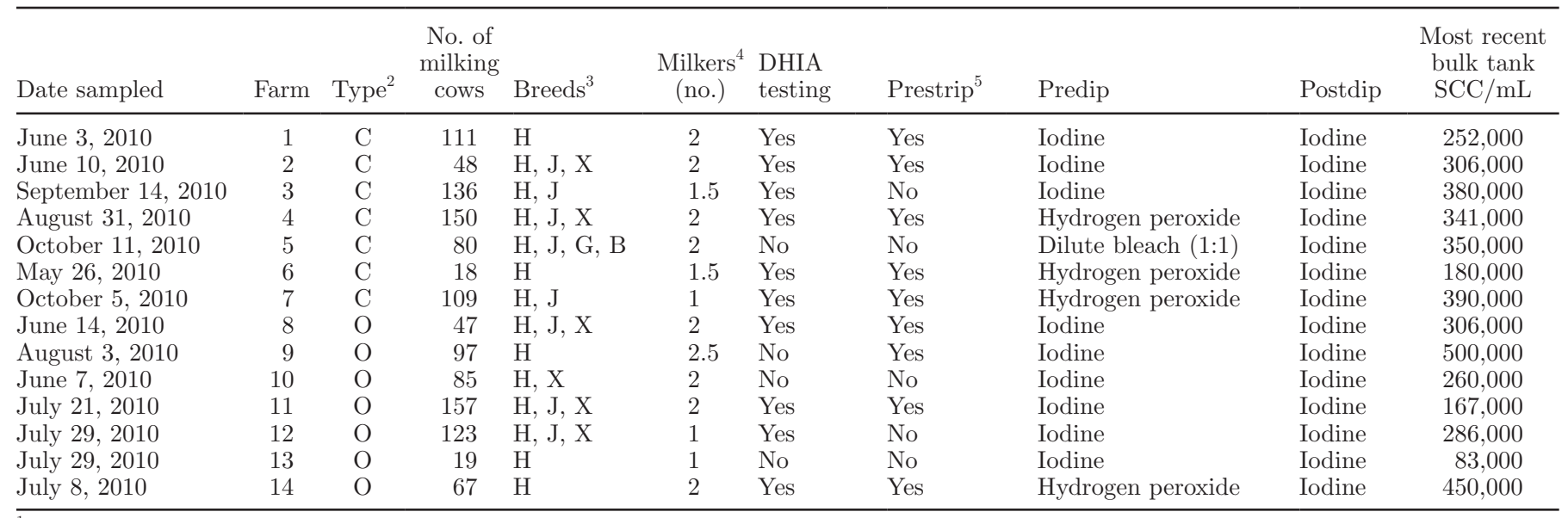

${ }^{1}$ This study was conducted between May and October of 2010 on all certified organic dairies $(\mathrm{n}=6)$ in North Carolina, 6 conventional dairies of similar size and geographic location, and a research herd managed half conventionally (farm 2) and half organically (farm 8). Organic cows in that herd received health care and pasture access according to US Department of Agriculture organic standards but consumed conventional concentrate feed supplements.

${ }^{2} \mathrm{C}=$ conventional; $\mathrm{O}=$ organic.

${ }^{3} \mathrm{H}=$ Holsteins; $\mathrm{J}=$ Jerseys; $\mathrm{X}=$ Holstein $\times$ Jersey crossbreds; $\mathrm{G}=$ Guernsey, $\mathrm{B}=$ Brown Swiss.

${ }^{4}$ Average number of people milking the cows at any one time. Some farms $(2,3,6$, and 8$)$ had rotations that involved multiple different milkers over time.

${ }^{5}$ Hand-milking a few strips before milking machine attachment.

and from 83,000 to 500,000 cells $/ \mathrm{mL}$ in organic herds (Table 1). All herds except 1 organic herd used fly control. Conventional farms used topical control (5 farms), bait (4 farms), ear tags ( 2 farms), traps ( 1 farm), or a cow vacuum (1 farm) for fly control. Organic farms used topical control (3 farms), traps (3 farms), biological controls (4 farms), repellents (3 farms), or a cow vacuum (1 farm) for fly control.

Milking Procedures. Eight of the 14 herds had 2 people in the milking parlor during milking time, as shown in Table 1. Nine of the 14 farms ( 5 conventional and 4 organic) reportedly checked foremilk by handmilking before attaching the milking unit (i.e., prestrip; Table 1). At the time of the survey, all herds used premilking teat dip. Nine farms used an iodine-based premilking teat dip, 4 used hydrogen peroxide-based teat dips, and 1 used a dilute bleach solution (Table 1). All herds used an iodine-based postmilking teat dip.

Mastitis Detection, Treatment, and Prevention. All herds used the California Mastitis Test, SCC records, or both, to detect subclinical mastitis (data not shown). All herds except 1 conventional herd treated subclinical mastitis; the organic herds used a range of treatments from essential oils to topical garlic application at the tailhead (Table 2). Clinical mastitis was most often detected by checking foremilk (9 farms) or by visual assessment of behavior and the mammary gland ( 7 farms), as shown in Table 2. All conventional herds used an intramammary antibiotic to treat clinical mastitis (Table 2). Treatments for clinical mastitis in organic dairy cattle mirrored organic treatments used for subclinical mastitis (Table 2).

All conventional herds used an antibiotic as part of the dry-off protocol and 4 herds also used an internal bismuth subnitrate teat sealant (Orbeseal; Zoetis Inc., Florham Park, NJ). Only 1 organic herd used an intramammary treatment (Phyto-Mast; Penn Dutch Cow Care, Narvon, PA) at dry off. The rest of the organic herds did not use any treatments at dry off. Three organic herds gradually reduced milking frequency at the end of lactation just before dry off (Table 2).

\section{Milk Quality}

A total of 4,793 quarter milk samples $(2,526$ conventional and 2,267 organic) were collected from 1,247 cows (652 conventional and 595 organic). Eighty-three quarter samples $(3.3 \%)$ of 2,526 collected from conventional cows and 50 quarter samples $(2.2 \%)$ of 2,267 collected from organic cows were unusable due to contamination and are not included in the microbiological analyses.

Somatic cell score did not differ significantly between conventional $(3.3 \pm 0.2)$ and organic $(3.5 \pm 0.2)$ herds $(P=0.75)$, although great variation existed among herds within both management types (Figure 1). The proportion of cows with subclinical mastitis did not differ significantly $(P=0.72)$ between conventional $(20.8 \%)$ and organic $(23.3 \%)$ herds. 
Table 2. Detection and treatment of mastitis and dry-off treatments used by 7 conventional and 7 organic dairy farms in North Carolina ${ }^{1}$

\begin{tabular}{|c|c|c|c|c|c|}
\hline Farm & Type $^{2}$ & Subclinical mastitis treatment ${ }^{3}$ & Clinical mastitis detection & Clinical mastitis treatment ${ }^{3}$ & Dry-off protocol \\
\hline 1 & $\mathrm{C}$ & $\begin{array}{l}\text { Cephapirin sodium, pirlimycin } \\
\text { hydrochloride, or ceftiofur hydrochloride }\end{array}$ & Check foremilk, behavior & $\begin{array}{l}\text { Flunixin meglumine, cephapirin } \\
\text { sodium, pirlimycin hydrochloride, } \\
\text { or ceftiofur hydrochloride }\end{array}$ & $\begin{array}{l}\text { Penicillin-dihydrostreptomycin and } \\
\text { bismuth subnitrate }\end{array}$ \\
\hline 2 & $\mathrm{C}$ & Pirlimycin hydrochloride & $\begin{array}{l}\text { Check foremilk, behavior, also } \\
\text { assessed using } \text { CMT }^{4}\end{array}$ & Pirlimycin hydrochloride & $\begin{array}{l}\text { Penicillin-dihydrostreptomycin and } \\
\text { bismuth subnitrate }\end{array}$ \\
\hline 3 & $\mathrm{C}$ & $\begin{array}{l}\text { Pirlimycin hydrochloride or ceftiofur } \\
\text { hydrochloride }\end{array}$ & Visual, confirmed using CMT & $\begin{array}{l}\text { Hetacillin potassium or ceftiofur } \\
\text { hydrochloride }\end{array}$ & Penicillin-dihydrostreptomycin \\
\hline 4 & $\mathrm{C}$ & $\begin{array}{l}\text { Cephapirin sodium or pirlimycin } \\
\text { hydrochloride }\end{array}$ & Check foremilk & $\begin{array}{l}\text { Cephapirin sodium or pirlimycin } \\
\text { hydrochloride }\end{array}$ & $\begin{array}{l}\text { Penicillin-dihydrostreptomycin and } \\
\text { bismuth subnitrate }\end{array}$ \\
\hline 5 & $\mathrm{C}$ & $\begin{array}{l}\text { Cephapirin sodium, pirlimycin } \\
\text { hydrochloride, or ceftiofur hydrochloride }\end{array}$ & Visual & $\begin{array}{l}\text { Cephapirin sodium, pirlimycin } \\
\text { hydrochloride, or ceftiofur } \\
\text { hydrochloride }\end{array}$ & $\begin{array}{l}\text { Benzathine cloxacillin or cephapirin } \\
\text { benzathine }\end{array}$ \\
\hline 6 & $\mathrm{C}$ & Nothing & Check foremilk & Ceftiofur hydrochloride & Ceftiofur hydrochloride \\
\hline 7 & $\mathrm{C}$ & Ceftiofur hydrochloride & $\begin{array}{l}\text { Check foremilk, also assessed using } \\
\text { CMT }\end{array}$ & Pirlimycin hydrochloride & $\begin{array}{l}\text { Cephapirin benzathine and bismuth } \\
\text { subnitrate }\end{array}$ \\
\hline 8 & $\mathrm{O}$ & Phyto-Mast $^{5}$ & $\begin{array}{l}\text { Check foremilk, also assessed using } \\
\text { CMT, visual, SCC }\end{array}$ & Phyto-Mast & Phyto-Mast \\
\hline 9 & $\mathrm{O}$ & Phyto-Mast, garlic oral or in vulva & Visual & Phyto-Mast, garlic oral or in vulva & No treatment \\
\hline 10 & $\mathrm{O}$ & Essential oils, garlic tinctures & Visual & Essential oils, garlic tinctures & 3 mo dry \\
\hline 11 & $\mathrm{O}$ & Phyto-Mast & Check foremilk & Garlic tinctures, Phyto-Mast & No treatment \\
\hline 12 & $\mathrm{O}$ & Garlic, Aloe vera, Echinacea, topical rub & Check foremilk, SCC & Garlic, Aloe vera, topical rub & Milk 1 time/d for 4 to $5 \mathrm{~d}$ and dry off \\
\hline 13 & $\mathrm{O}$ & Strip out, garlic at tailhead, oral Aloe vera & Behavior, also assessed using CMT & $\begin{array}{l}\text { Strip out, garlic at tailhead, oral } \\
\text { Aloe vera }\end{array}$ & $\begin{array}{l}\text { First } 3 \mathrm{~d} \text { milk every other milking, every } \\
2 \mathrm{~d} \text { for } 2 \text { times, wait } 1 \mathrm{wk} \text {, milk out if } \\
\text { there is still milk }\end{array}$ \\
\hline 14 & $\mathrm{O}$ & Garlic tincture in vulva & Check foremilk & Garlic tincture in vulva & Dry and 1 wk later milk out \\
\hline
\end{tabular}

${ }^{1}$ This study was conducted between May and October of 2010 on all certified organic dairies $(\mathrm{n}=6)$ in North Carolina, 6 conventional dairies of similar size and geographic loca-

¿ tion, and a research herd managed half conventionally (farm 2) and half organically (farm 8). Organic cows in that herd received health care and pasture access according to US Department of Agriculture (USDA) organic standards but consumed conventional concentrate feed supplements.

$\stackrel{2}{2} \mathrm{C}=$ conventional management; $\mathrm{O}=$ organic management.

$\stackrel{\text { O. }}{3}$ In some mastitis cases, farmers may use more than 1 treatment.

$\stackrel{N^{2}}{\stackrel{4}{\Sigma}} \mathrm{CMT}=$ California mastitis test.

Phyto-Mast is an intramammary herbal product (Penn Dutch Cow Care, Narvon, PA). 


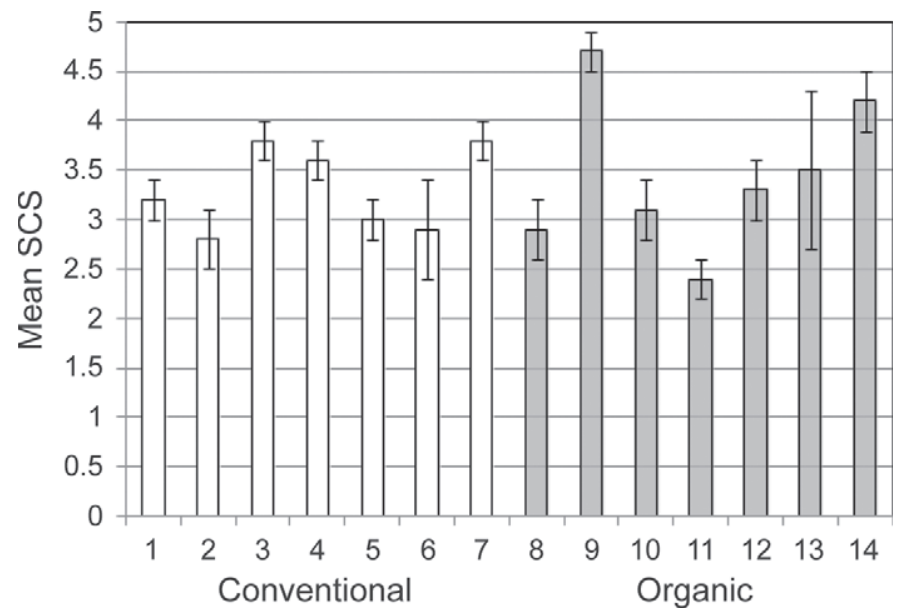

Figure 1. Mean SCS of 7 conventional and 7 organic dairies in North Carolina. This study was conducted between May and October of 2010 on all certified organic dairies $(n=6)$ in North Carolina, 6 conventional dairies of similar size and geographic location, and a research herd managed half conventionally (farm 2) and half organically (farm 8). Organic cows in that herd received health care and pasture access according to US Department of Agriculture organic standards but consumed conventional concentrate feed supplements.

The proportion of cows with negative microbiological results did not differ between conventional (49.8\%) and organic $(34.1 \%)$ dairies $(P=0.27)$. No significant differences were observed between management type for cow-level prevalence of Staph. aureus (4.1\% conventional vs. $4.7 \%$ organic; $P=0.75)$, CNS $(20.6 \%$ conventional vs. $14.1 \%$ organic; $P=0.17$ ), Streptococcus spp. $(2.2 \%$ conventional vs. $2.9 \%$ organic; $P=0.66)$, or Corynebacterium spp. (2.8\% conventional vs. $6.6 \%$ organic; $P=0.33)$. The proportion of cows with minor species infections (CNS, Corynebacterium spp., or both CNS and Corynebacterium spp.) also did not differ between management types $(26.5 \%$ conventional vs. $30.4 \%$ organic; $P=0.64$ ).

The frequency of intramammary infections in individual quarter milks is presented in Table 3. In all conventional herds and the majority of organic herds, CNS was the organism most frequently isolated from infected quarters. Presence of Staph. aureus alone in quarter milk ranged from 0.5 to $4.8 \%$ in conventional herds and from 2.7 to $6.8 \%$ in organic herds (Table 3 ). Corynebacterium spp. (presumed bovis) were frequently found in organic herds, but percentages of infected glands were quite variable, ranging from 0 to $63.5 \%$. High prevalence of Corynebacterium spp. was related to high average herd SCS in 2 organic herds (Table 3; Figure 1; Figure 2b). The prevalence of environmental pathogens varied greatly by farm, with the highest frequency of coliforms found in herd 7 (conventional) and the highest proportion of Streptococcus spp. (not agalactiae) found in herd 13 (organic). Coliform organ- isms were found in 1 of the 7 organic herds and were detected in 5 of the 7 conventional herds. Table 3 also shows that the most common result was a single organism per quarter. For example, the large majority of Staph. aureus quarter infections were single and not mixed infections (e.g., Staph. aureus and CNS).

\section{DISCUSSION}

The objective of this study was to assess milk quality and mastitis management practices in similarly sized organic and conventional dairies in North Carolina. This study provides a snapshot of similarities and differences between regionally matched dairies during the warmest months of the year in a region of the United States with a history of challenges regarding milk quality. Interpretation of the data should be done cautiously, as this single sampling of each farm may not adequately represent milk quality over multiple years.

Milk quality on organic farms is of great interest to both consumers and dairy scientists. The potential for variation in milk quality on organic dairies compared with conventional dairies is certainly of concern with the steady growth of the organic dairy industry. We expected that SCS might be greater in organic dairies than conventional dairies because the weather over the duration of the study was highly conducive to heat stress and organic producers would not have access to antibiotics for use in managing udder health. The average temperature-humidity index during the study was above 72 , the standard index value used to indicate heat stress in dairy cattle (Armstrong, 1994). Despite these potential challenges, our results indicate that no difference existed in SCS between the organic and conventional dairy herds sampled. Comparisons are difficult to make between United States and international organic dairies due to differences in regulations on use of antibiotics (Ruegg, 2009). For example, European Union organic regulations allow the use of antibiotics to treat disease when the use of non-synthetic products is inappropriate, but with an extended withdrawal time (The Council of the European Union, 2007). Even with differences in regulations, no clear patterns of differences exist in SCC between organic and conventional dairies in the United States or other countries. Most previous comparisons of organic and conventional dairies in the United States have reported no significant differences in bulk tank SCC (Sato et al., 2005; Pol and Ruegg, 2007b; Stiglbauer et al., 2013; Cicconi-Hogan et al., 2013). Some studies in Norway (Valle et al., 2007) and Sweden (Hamilton et al., 2006; Fall et al., 2008) have also reported similar bulk tank SCC between management types. One study of dairies in Michigan, Minnesota, New York, and Wisconsin reported higher SCC 
Table 3. Frequency of udder quarters with various intramammary infections on 7 conventional and 7 organic dairies in North Carolina ${ }^{1}$

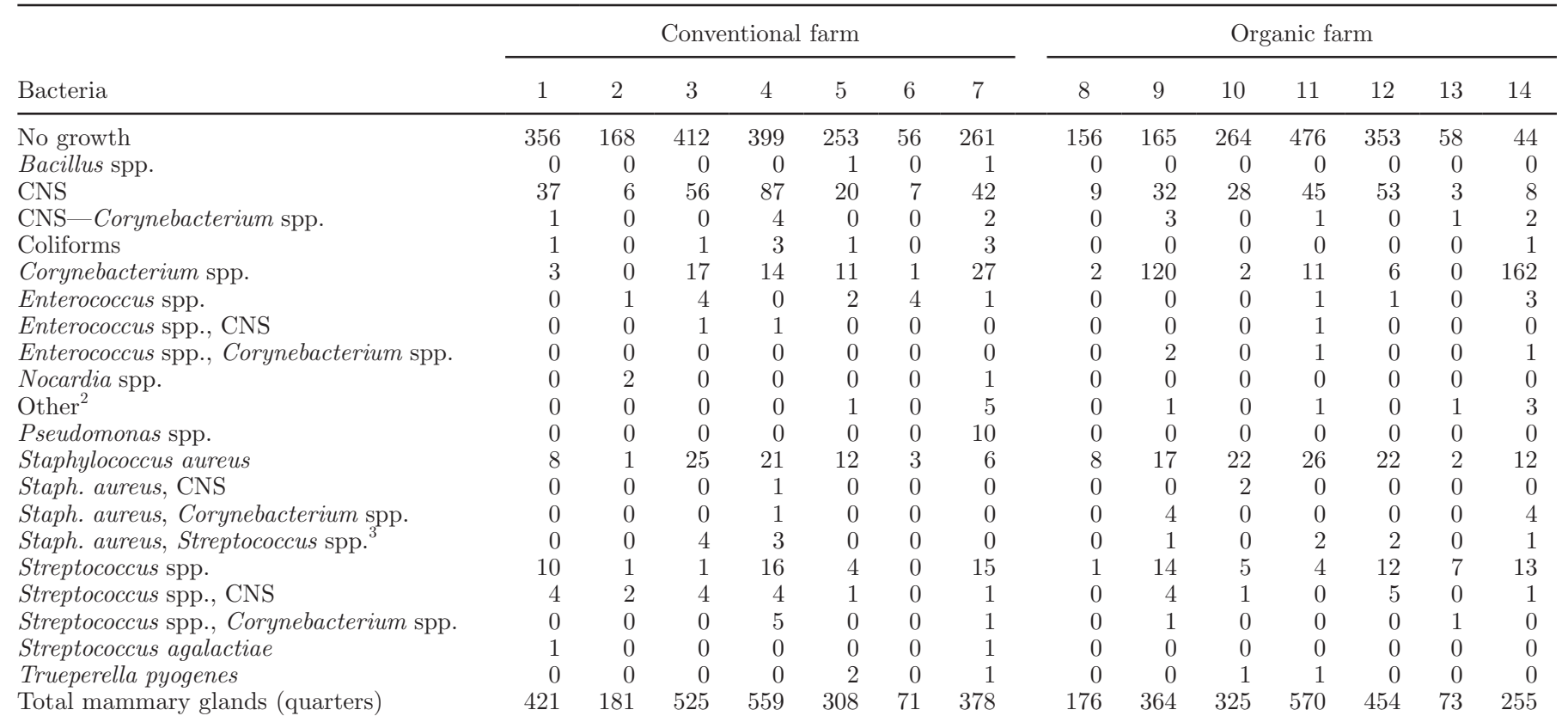

${ }^{1}$ This study was conducted between May and October of 2010 on all certified organic dairies $(\mathrm{n}=6)$ in North Carolina, 6 conventional dairies of similar size and geographic location, and a research herd managed half conventionally (farm 2) and half organically (farm 8). Organic cows in that herd received health care and pasture access according to US Department of Agriculture (USDA) organic standards but consumed conventional concentrate feed supplements.

${ }^{2}$ One quarter infected with yeast and Streptococcus spp. (farm 5); 2 Pseudomonas spp. and CNS, 2 Pseudomonas spp. and Pasteurella, and 1 Streptococcus spp. and Escherichia coli (farm 7); 1 yeast (farm 9); 1 Trueperella pyogenes and Streptococcus spp. (farm 11); 1 Serratia marcescens (farm 13); 1 Corynebacterium spp. and E. coli, 1 gram-negative, and 1 Streptococcus agalactiae and Corynebacterium spp. (farm 14).

${ }^{3}$ Streptococcus spp. $=$ Streptococcus spp. other than agalactiae.

in organic dairies compared with conventional dairies (Zwald et al., 2004). Higher bulk tank SCC were also seen in organic herds in Norway (Hardeng and Edge, 2001), the United Kingdom (Hovi and Roderick, 2000), and Switzerland (Roesch et al., 2007). Evidence from Finland suggests that organic milk has significantly higher SCC than conventional milk in the summertime (Luukkonen et al., 2005). In contrast, bulk tank SCC was lower in organic herds $(273,000$ cells $/ \mathrm{mL})$ than in conventional herds $(559,300$ cells $/ \mathrm{mL})$ in spring and summer in New York and Vermont (Tikofsky et al., 2003). No clear relationships exist between SCC and organic or conventional dairy management.

Successful mastitis prevention strategies include application of a germicidal teat dip postmilking and treating all cows with intramammary antibiotics at dry off; both of these management practices are associated with lower SCC than not using teat dip or treating all cows at dry off (Erskine and Eberhart, 1991; Wenz et al., 2007; Dufour et al., 2011). All farms that we surveyed used an iodine-based postmilking teat dip. Most organic farms previously surveyed in the United States use postmilking teat dip (Sato et al., 2005; Stiglbauer et al., 2013). Many of the conventional farms used US Food and Drug Administration (FDA)-approved intramammary antibiotics on all cows at dry off. A considerable majority of conventional herds in the United States use antibiotic dry cow therapy on all cows (USDA, 2007). The use of blanket dry cow therapy is not possible in United States organic dairies because the USDA prohibits administration of any drug in the absence of illness in organic dairy cattle, except for vaccines (USDA National Organic Program, 2013). Many organic farms use gradual cessation of milking to dry off their cows, as seen in our survey (Table 2) as well as in most organic farms surveyed in Wisconsin (Ruegg, 2009). Gradual cessation of milking at dry off has been associated with less milk leakage post-dry off compared with abruptly drying off (Zobel et al., 2013). Less milk leakage could ostensibly allow for more rapid formation of the keratin teat plug, providing a natural source of resistance to mastitis during the dry period.

Treatment and prevention of mastitis in organic dairy cattle in the United States is challenging because most products used by organic producers for mastitis treatment have limited scientific evidence of efficacy. Organic farmers in this survey used Phyto-Mast, garlic, essential oils, or Aloe vera for treating subclinical and 

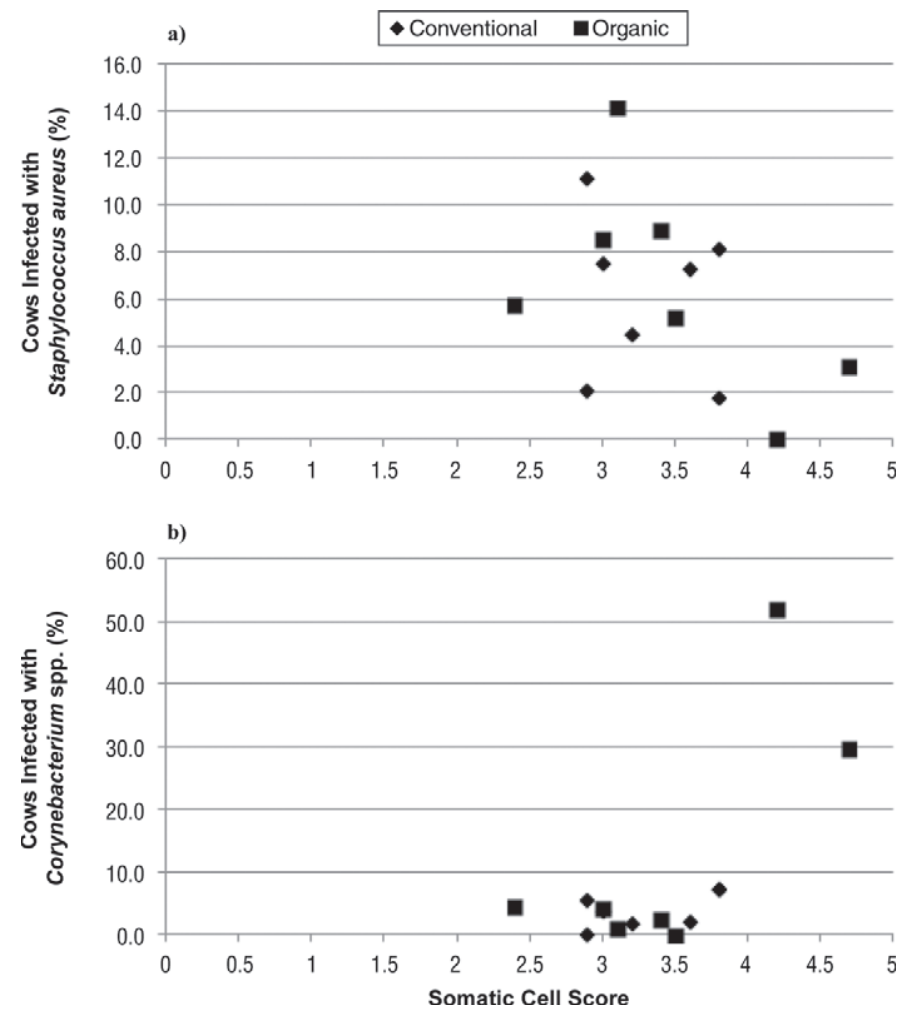

Figure 2. Relationship between herd mean SCS and percentage of cows infected with 2 contagious mastitis-causing organisms [Staphylococcus aureus (a) and Corynebacterium spp. (b)]. This study was conducted between May and October of 2010 on all certified organic dairies $(\mathrm{n}=6)$ in North Carolina, 6 conventional dairies of similar size and geographic location, and a research herd managed half conventionally and half organically. Organic cows in that herd received health care and pasture access according to US Department of Agriculture organic standards but consumed conventional concentrate feed supplements.

clinical mastitis. Organic dairy farmers in Wisconsin have been reported to use whey-based products, garlic tinctures, Aloe vera, vitamin C, aspirin, homeopathy, and vegetable oils to treat clinical mastitis ( $\mathrm{Pol}$ and Ruegg, 2007b). No studies currently available validate the use of garlic, essential oils, or Aloe vera as therapy for bovine mastitis. One study has shown that PhytoMast has similar efficacy to antibiotic therapy for curing infections when used as a dry-off treatment (Mullen et al., 2012), but Phyto-Mast has not been evaluated for treatment of mastitis during lactation. Intravaginal or intramammary treatments used by organic farmers in the United States have not been approved by the FDA for treatment of mastitis. Further evaluation of alternatives to antibiotics is essential to determine effective treatments for organic dairy producers to use as mastitis therapy when infections occur.

A wide range of SCS was observed among farms within management types, which could be due, in part, to prevalence of certain bacteria such as Corynebacterium spp. and Staph. aureus. Infection with Corynebacterium bovis has been shown to increase SCC 2 to 3 times relative to uninfected cows (NMC, 1996). The 2 organic herds with the highest SCS also had very high rates of infection with Corynebacterium spp. (Table 3; Figure 1; Figure 2b), which is problematic because of the known relationship between $C$. bovis infection and elevated SCC. We believe that isolated Corynebacterium spp. were $C$. bovis, although the authors recognize that a small chance $(\sim 3 \%)$ exists that this is an incorrect assumption based on the lack of further testing for speciation (Huxley et al., 2004). The infection rate in those organic herds is of concern because of the lack of treatments for mastitis that are approved by the FDA and the USDA National Organic Program. The increase in SCS for some organic herds in this study is also of concern for milk quality.

Organic herds had a numerically higher cow-level prevalence of Staph. aureus in the current study $(4.7 \%$ of cows infected vs. $4.1 \%$ of conventional cows infected). Other studies on organic herds in the United States have found the prevalence of Staph. aureus to be numerically different, either lower (Tikofsky et al., 2003) or higher (Sato et al., 2004; Pol and Ruegg, 2007b; Cicconi-Hogan et al., 2013). The prevalence of Staph. aureus on Wisconsin dairies with 6-mo average bulk tank $\mathrm{SCC} \geq 250,000$ cells $/ \mathrm{mL}$ was significantly greater in organic herds compared with conventional herds ( $\mathrm{Pol}$ and Ruegg, 2007a), and presence of Staph. aureus is a risk factor for high SCC on organic dairies in the United States (Cicconi-Hogan et al., 2013). The probability of curing a Staph. aureus infection decreases as cow age and duration of infection increase (Barkema et al., 2006). Organic dairies tend to have older cows than conventional dairies (Stiglbauer et al., 2013), and the lack of approved treatments for bovine mastitis in organic cattle could also contribute to the higher prevalence of Staph. aureus in organic dairies. The relatively higher prevalence of Staph. aureus in organic dairies could also be related to lack of use of practices such as dry-cow treatment and challenges in controlling fly populations: synthetic insecticides are not permitted for use on organic dairies (USDA National Organic Program, 2013). Horn flies (Haematobia irritans) are blood-feeding flies active during the summer months that have been shown to be possible vectors for Staph. aureus on dairies in North Carolina (Anderson et al., 2012). In the case of those organic herds with high prevalence of Corynebacterium spp. and Staph. aureus, we recommend selectively culling cows with high SCC and presence of IMI. Aggressively culling for Staph. aureus mastitis, effective fly control, and maintaining 
a clean environment are essential to reducing incidence of Staph. aureus mastitis on both organic and conventional herds.

\section{CONCLUSIONS}

Despite differences in mastitis treatment availability, organic and conventional dairies surveyed in North Carolina had similar cow-level SCS and prevalence of several mastitis-causing bacteria, including Staphylococcus aureus, Streptococcus spp., Corynebacterium spp., and coagulase-negative Staphylococcus spp. Our data indicate that conventional and organic dairy farmers in the southeastern United States face similar challenges in mastitis management and milk quality during the warm months of the year.

\section{ACKNOWLEDGMENTS}

This project was funded in part by a USDA Southern Region Sustainable Agriculture Research and Education Grant and from the Merck-Merial Veterinary Scholars Program at the North Carolina State University College of Veterinary Medicine (Raleigh). The authors thank Consuelo Arellano of the North Carolina State University Statistics Department. The authors also acknowledge the dairy farmers who participated in this study.

\section{REFERENCES}

Anderson, K. L., R. Lyman, K. Moury, D. Ray, D. W. Watson, and M. T. Correa. 2012. Molecular epidemiology of Staphylococcus aureus mastitis in dairy heifers. J. Dairy Sci. 95:4921-4930.

Armstrong, D. V. 1994. Heat stress interaction with shade and cooling. J. Dairy Sci. 77:2044-2050.

Barkema, H. W., Y. H. Schukken, and R. N. Zadoks. 2006. Invited review: The role of cow, pathogen, and treatment regimen in the therapeutic success of bovine Staphylococcus aureus mastitis. J. Dairy Sci. 89:1877-1895.

Cicconi-Hogan, K. M., M. Gamroth, R. Richert, P. L. Ruegg, K. E. Stiglbauer, and Y. H. Schukken. 2013. Associations of risk factors with somatic cell count in bulk tank milk on organic and conventional dairy farms in the United States. J. Dairy Sci. 96:3689 3702.

Dufour, S., A. Fréchette, H. W. Barkema, A. Mussell, and D. T. Scholl. 2011. Invited review: Effect of udder health management practices on herd somatic cell count. J. Dairy Sci. 94:563-579.

Erskine, R. J., and R. J. Eberhart. 1991. Post-milking teat dip use in dairy herds with high or low somatic cell counts. J. Am. Vet. Med. Assoc. 199:1734-1736.

Fall, N., U. Emanuelson, K. Martinsson, and S. Jonsson. 2008. Udder health at a Swedish research farm with both organic and conventional dairy cow management. Prev. Vet. Med. 83:186-195.

Giesecke, W. H. 1985. The effect of stress on udder health of dairy cows. Onderstepoort J. Vet. Res. 52:175-193.

Hamilton, C., U. Emanuelson, K. Forslund, I. Hansson, and T. Ekman. 2006. Mastitis and related management factors in certified organic dairy herds in Sweden. Acta Vet. Scand. 48:11-17.
Hardeng, F., and V. L. Edge. 2001. Mastitis, ketosis, and milk fever in 31 organic and 93 conventional Norwegian dairy herds. J. Dairy Sci. 84:2673-2679.

Hovi, M., and S. Roderick. 2000. Mastitis and mastitis control strategies in organic milk. Cattle Pract. 8:259-264.

Huxley, J. N., C. R. Helps, and A. J. Bradley. 2004. Identification of Corynebacterium bovis by endonuclease restriction analysis of the 16S rRNA gene sequence. J. Dairy Sci. 87:38-45.

Luukkonen, J., A. Kemppinen, M. Kärki, H. Laitinen, M. Mäki, S. Sivelä, A.-M. Taimisto, and E.-L. Ryhänen. 2005. The effect of a protective culture and exclusion of nitrate on the survival of enterohemorrhagic E. coli and Listeria in Edam cheese made from Finnish organic milk. Int. Dairy J. 15:449-457.

Mullen, K. A. E., R. L. Lyman, S. P. Washburn, and K. L. Anderson. 2012. Efficacy of two herbal remedies as alternatives to antibiotic dry cow therapy: Preliminary microbiology results. J. Dairy Sci. 95(Suppl. 2):443. (Abstr.)

NMC (National Mastitis Council). 1996. Current Concepts of Bovine Mastitis. 4th ed. NMC, Madison, WI.

NMC (National Mastitis Council). 1999. Laboratory Handbook on Bovine Mastitis. NMC, Madison, WI

Norman, H. D., R. H. Miller, J. R. Wright, and G. R. Wiggans. 2000. Herd and state means for somatic cell count from Dairy Herd Improvement. J. Dairy Sci. 83:2782-2788.

Olynk, N. J., G. T. Tonsor, and C. A. Wolf. 2010. Consumer willingness to pay for livestock credence attribute claim verification. J. Agric. Resour. Econ. 35:261-280.

Organic Trade Association. 2011. U. S. organic industry overview. Accessed Feb. 2, 2013. http://www.ota.com/pics/documents/2011Or ganicIndustrySurvey.pdf.

Pol, M., and P. L. Ruegg. 2007a. Relationship between antimicrobial drug usage and antimicrobial susceptibility of gram-positive mastitis pathogens. J. Dairy Sci. 90:262-273.

Pol, M., and P. L. Ruegg. 2007b. Treatment practices and quantification of antimicrobial drug usage in conventional and organic dairy farms in Wisconsin. J. Dairy Sci. 90:249-261.

Roesch, M., M. G. Doherr, W. Schären, M. Schällibaum, and J. W. Blum. 2007. Subclinical mastitis in dairy cows in Swiss organic and conventional production systems. J. Dairy Res. 74:86-92.

Ruegg, P. L. 2009. Management of mastitis on organic and conventional dairy farms. J. Anim. Sci. 87:43-55.

Sato, K., P. C. Bartlett, R. J. Erskine, and J. B. Kaneene. 2005. A comparison of production and management between Wisconsin organic and conventional dairy herds. Livest. Prod. Sci. 93:105-115.

Sato, K., T. W. Bennedsgaard, P. C. Bartlett, R. J. Erskine, and J. B. Kaneene. 2004. Comparison of antimicrobial susceptibility of Staphylococcus aureus isolated from bulk tank milk in organic and conventional dairy herds in the Midwestern United States and Denmark. J. Food Prot. 67:1104-1110.

Shook, G. E. 1982. Approaches to summarizing somatic cell count which improve interpretability. Page 150 in Proc. 21st Annu. Mtg. Natl. Mastitis Counc., Arlington, VA. Natl. Mastitis Counc., Verona, WI.

Smith. D. L., T. Smith, B. J. Rude, and S. H. Ward. 2013. Short communication: Comparison of the effects of heat stress on milk and component yields and somatic cell score in Holstein and Jersey cows. J. Dairy Sci. 96:3028-3033.

State Climate Office of North Carolina. 2013. Climate Division data. Accessed May 27, 2013. http://www.nc-climate.ncsu.edu/.

Stiglbauer, K. E., K. M. Cicconi-Hogan, R. Richert, Y. H. Schukken, P. L. Ruegg, and M. Gamroth. 2013. Assessment of herd management on organic and conventional dairy farms in the United States. J. Dairy Sci. 96:1290-1300.

The Council of the European Union. 2007. Council Regulation (EC) No 834/2007 of 28 June 2007 on organic production and labelling of organic products and repealing Regulation (EEC) No 2092/91. Accessed Mar. 15, 2013. http://eur-lex.europa.eu/LexUriServ/ LexUriServ.do?uri=OJ:L:2007:189:0001:0023:EN:PDF.

Tikofsky, L. L., J. W. Barlow, C. Santisteban, and Y. H. Schukken. 2003. A comparison of antimicrobial susceptibility patterns for 
Staphylococcus aureus in organic and conventional dairy herds. Microb. Drug Resist. 9(Suppl. 1):S39-S45.

USDA (US Department of Agriculture). 2007. Dairy 2007: Part III: Reference of Dairy Cattle Health and Management Practices in the United States, 2007. USDA-Animal and Plant Health Inspection Service-Veterinary Services-Centers for Epidemiology and Animal Health (USDA-APHIS-VS-CEAH), Fort Collins, CO.

USDA National Organic Program. 2013. Organic livestock requirements. Accessed Feb. 22, 2013. http://www.ams.usda.gov/ AMSv1.0/getfile?dDocName=STELPRDC5102526.

Valle, P. S., G. Lien, O. Flaten, M. Koesling, and M. Ebbesvik. 2007. Herd health and health management in organic versus conventional dairy herds in Norway. Livest. Sci. 112:123-132.
Wenz, J. R., S. M. Jensen, J. E. Lombard, B. A. Wagner, and R. P. Dinsmore. 2007. Herd management practices and their association with bulk tank somatic cell count on United States dairy operations. J. Dairy Sci. 90:3652-3659.

Zobel, G., K. Leslie, D. M. Weary, and M. A. G. von Keyserlingk. 2013. Gradual cessation of milking reduces milk leakage and motivation to be milked in dairy cows at dry-off. J. Dairy Sci. 96:5064-5071.

Zwald, A. G., P. L. Ruegg, J. B. Kaneene, L. D. Warnick, S. J. Wells, C. Fossler, and L. W. Halbert. 2004. Management practices and reported antimicrobial usage on conventional and organic dairy farms. J. Dairy Sci. 87:191-201. 